\title{
A pilot weed management programme for bat-wing passion flower in New Zealand
}

\author{
H.G. Pearson ${ }^{1}$, S. Christian², A. Baldwin², D. Yard $^{2}$ and P. Coates ${ }^{3}$ \\ ${ }^{1}$ Ministry of Agriculture and Forestry, PO Box 2095, Auckland 1140, New Zealand \\ ${ }^{2}$ Ministry of Agriculture and Forestry, PO Box 2526, Wellington 6140, New Zealand \\ ${ }^{3}$ AsureQuality, Private Bag 14946, Auckland 1741, New Zealand \\ Corresponding author: heather.pearson@maf.govt.nz
}

Passiflora apetala (bat-wing passion flower) was introduced as an ornamental variety in the mid-1990s and has been dispersed in New Zealand through the activities of sub-tropical plant collectors and avian vectors. Although $P$. apetala is currently restricted to the Northland and Auckland regions of the North Island, some closely related Passiflora species have become serious weeds in New Zealand. A pilot weed management programme was implemented to undertake intensive surveillance and organism management of all $P$. apetala plants to significantly reduce the rate of naturalisation at two sites: a heavily infested rural site and an urban/residential location. The objectives of the management programme were to assess the feasibility, effectiveness and costs of local elimination attempts and to inform partners of future management options for this species.

\section{Threat of Turnip mosaic virus strains to rare and endangered native Lepidium spp. in the South Island, New Zealand}

\author{
J.D. Fletcher ${ }^{1}$, S.R. Bulman ${ }^{1}$, J. van Vianen², P.B. Heenan ${ }^{3}$ and G.J. Houliston ${ }^{3}$ \\ ${ }^{1}$ The New Zealand Institute for Plant \& Food Research Limited, Private Bag 4704, Christchurch, \\ New Zealand \\ ${ }^{2}$ School of Biological Sciences, University of Canterbury, Private Bag 4800, Christchurch, \\ New Zealand \\ ${ }^{3}$ Manaaki Whenua-Landcare Research, PO Box 40, Lincoln 7640, New Zealand \\ Corresponding author: fletcherj@crop.cri.nz
}

Cook's scurvy grass (Lepidium oleraceum agg.) is an endangered species of native Brassicaceae that is considered threatened by extinction. Virus-like disease symptoms were observed in a newly introduced plant of L. oleraceum at Stony Bay, Banks Peninsula, Canterbury, New Zealand, in 2008. Turnip mosaic virus (TuMV) was subsequently confirmed as the cause of symptoms. A survey was undertaken at seven isolated South Island sites where L. oleraceum and other Lepidium species were growing. TuMV was detected in around $20 \%$ of plants at two sites. Cauliflower mosaic virus (CaMV) was also detected at three sites with up to 50\% incidence at one site and there was some evidence of a Beet western yellows virus (BWYV) infection. Further isolates of TuMV were also collected from commercial brassica crops in the South Island. RT PCR products for all of the virus-infected plant material were sequenced, analysed phylogenetically and compared. This poster reports on survey results and the comparative phylogenetic analysis of the TuMV isolates. 